\title{
Design and Empirical Inquisition of Catalytic Combustor for Methanol Steam Reformer in HT-PEM Fuel Cell Systems
}

\author{
Abhijeet Chougule, Ramakrishna R. Sonde
}

\begin{abstract}
Steam reforming of methanol is a basic endothermic reaction. For which, a separate external system is required for generation of heat. The reaction speeds are controlled by operating temperature and heat transfer rate to the reactor. This operating temperature has a very narrow window of operation. It is therefore extremely important to have a system that generates controlled combustion based stable heat for providing required heat to reformer.
\end{abstract}

A design of catalytic combustor was developed and analyzed for methanol steam reformer. The packed bed of combustion catalyst provides active sites for combustion of the methanol water mixture during start-up and later for combustion of anode exhaust gas (AEG) during normal operation. The combustion reactions and their thermodynamics were studied for commercial catalyst. System design was simulated using Engineering Equation Solver (EES) software for determining the quantity of air required for combustion of fuel as well as for dilution of gases to maintain a temperature of $573 \mathrm{~K}$. The design was analyzed using ANSYS DISCOVERY LIVE for understanding the different operating condition(s) inside the combustor. It was also used to generate design of experiments to evaluate, build and demonstrate a catalytic combustor for on-board reformer for HT-PEM fuel cell system.

Keywords: Catalytic combustor, HT-PEM Fuel cell, Hydrogen generation, Methanol steam reformer, On-board reformer, Packed bed, Simulation.

\section{INTRODUCTION}

Methanol (Chemical formula: $\mathrm{CH}_{3} \mathrm{OH}$ ) is a single carbon-based organic compound which can be produced/ derived from fuels such as coal, biomass and natural gas. As per date reported in [1][2], Methanol is finding increasing acceptance as low carbon/carbon neutral fuel. It is an efficient and less polluting fuel with octane number 100, lesser emission of $\mathrm{NO}_{\mathrm{x}}$, particulate matter and no emission of $\mathrm{SO}_{\mathrm{X}}$. One of the important roles of methanol is in production of hydrogen for fuel cells. Hydrogen is the preferred fuel for fuel cell systems to get the best performance, but gaseous hydrogen is difficult to handle and store. It is therefore very attractive to use a material which can act as hydrogen-carrier

Revised Manuscript Received on April 25, 2020.

* Correspondence Author

Abhijeet Chougule*, Department of Technology, Savitribai Phule Pune University, Pune, India \& Thermax Limited, Pune India. Email: abhijeet.chougule@live.com; abhijeet.chougule@thermaxglobal.com

Ramakrishna R. Sonde, Thermax Limited, Pune, India. Email: r.sonde@thermaxglobal.com

(C) The Authors. Published by Blue Eyes Intelligence Engineering and Sciences Publication (BEIESP). This is an open access article under the CC BY-NC-ND license (http://creativecommons.org/licenses/by-nc-nd/4.0/) or "absorb" the hydrogen. Methanol is an excellent hydrogen-carrier and thus can be used as a fuel that stores hydrogen in liquid form for fuel cells. Hydrogen can be generated from methanol through catalytic processes, using a fuel reformer [1-3]. Reformer is a chemical reactor designed for steam reforming of methanol. It has a packed bed of $\mathrm{CuO} /$ $\mathrm{ZnO} / \mathrm{Al}_{2} \mathrm{O}_{3}$ catalyst inside an array of finned tubes. It receives feed from vaporizer in the form of superheated vapors and converts methanol into hydrogen by the steam reforming reaction. The main reactions that take place inside the steam reformer are: (a) Steam reforming of methanol, (b) Methanol decomposition and (c) Water gas shift reaction. Out of these three, the steam reforming and decomposition reaction are endothermic. The heat for these reactions is provided by the hot gases generated in the combustor. The hot gases flow over an array of reformer reactor tubes. These tubes are filled with packed bed of reforming catalyst. Being an exothermic reaction, the water gas shift reaction provides additional heat required to the endothermic reactions. Fig.1 shows the different streams in a methanol reformer-based fuel cell system. The methanol/water mixture is converted into hydrogen rich reformate gas by catalytic reactions. The endothermic reforming reaction takes place in a temperature range of $473 \mathrm{~K}$ to $573 \mathrm{~K}$ on copper/ zinc catalyst [3]. The heat for these reactions is supplied to the tubular reforming reactor through the walls heated with hot gas or liquid.

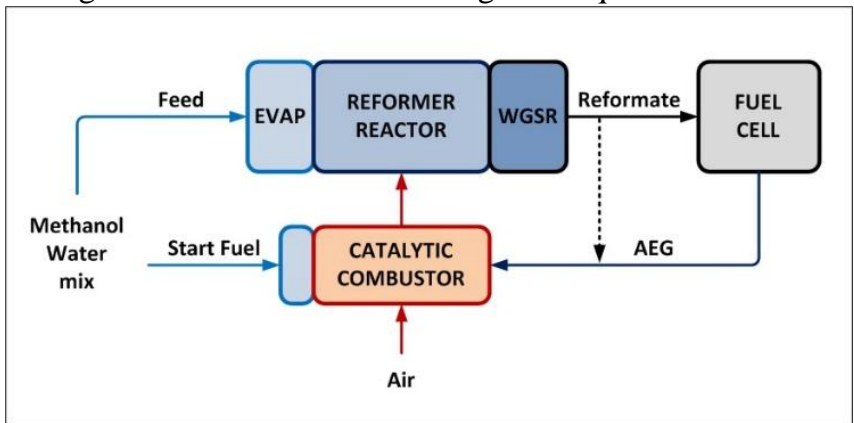

Fig. 1.Methanol reformer-based fuel cell system.

For use of methanol as a hydrogen carrier for smaller capacity (sub $10 \mathrm{~kW}$ ) fuel cell systems, the conventional steam reforming process must be scaled down. The integration of reformer and fuel cell requires effective heat integration within the system to achieve a better overall efficiency of fuel to electricity conversion [3-5].

Combining steam reformer (methanol steam reformer) with fuel cell (HT-PE fuel cell) is an efficient method of generating electrical energy.

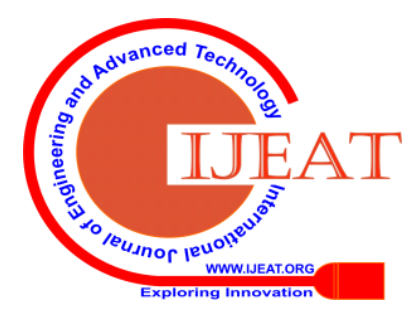


Recycling the anode exhaust gas as fuel for generating heat for the reformer enhances overall efficiency of the system. Literature [6][7] reports the increase of $>30 \%$ in fuel utilization due to anode exhaust gas.

The better overall efficiency can be achieved by incorporating the design of heat generation system based on catalytic combustion which can accept mix of fuel including methanol-water mixture, hydrogen rich reformate gas and the hydrogen lean anode exhaust gas. The combustor must handle all these types of fuel for efficient system operation and optimum fuel utilization during start-up as well as during normal operation.

Catalytic combustion, being a low temperature electro-chemical conversion process, is an alternative to conventional high temperature $(>1273 \mathrm{~K})$ flamed combustion and has substantial reduction in emissions. NOx emissions, a known dominant at higher temperature and being generally witnessed at conventional combustion mode, are lowered by incorporation of catalytic combustion. The catalytic combustion enables the reaction to take place at lower temperature due to the lower activation energy [8] and even a lean mixture of hydrogen (as in case of anode exhaust gas) can also undergo stable catalytic combustion [8-10].

The principle of catalytic combustion (conversion of chemical energy into thermal energy) process has matured from the fundamental work of Sir Humphrey Davy (1778-1829) [11][12]. Besides, the advantage of minimized emissions and the suitability towards fuel flexibility of handling multiple alternative fuels, the catalytic combustion also offer some other benefits such as - good temperature uniformity, robustness and simplicity in operation [8][13].

In general, catalytic combustion has been one of the well understood combustion techniques, but the effects of specific operating conditions such as variations in fuel compositions, flow rates, substrate type and catalyst loading, on performance of the catalytic combustor are not well understood. The catalytic reaction takes place on the active catalyst surface at temperatures below the ignition point of fuels such as methanol (737 K), hydrogen (773 K) and carbon monoxide (882 K).

The catalytic combustion with pre-mixed air-fuel gives lower emissions. Hence in this work the pre-mixing arrangement with provision for multiple fuel and air nozzles was chosen for investigation. This also brings in the advantage of having shorter length and time for mixing which also decreases possibilities of flashback and autoignition [8].

Based on available literature [9][14], the platinum on gamma alumina substrate is chosen as the combustion catalyst. Platinum has high activation energy which increases the rates of combustion reaction. This results in carrying out complete combustion of fuel at lower temperature [8][15].

\section{CATALYTIC COMBUSTOR}

It is a catalytic combustion based hot gas generator which is expected to have versatility of fuel from two/ three different streams during start-up, stabilization and normal operation. The catalytic combustor performs a dual role in this process design. During start-up, it is expected to combust methanol water mixture form fuel tank followed by an additional incoming stream of early reformate. Once the

reformate gas is supplied to fuel cell, the unreacted hydrogen, carbon monoxide and carbon dioxide from the anode exhaust stream is fed to the catalytic combustor as main fuel [16].

In catalytic combustor, there are three main combustion reactions and their reaction kinetics are considered - (a) methanol from methanol water mixture (b) hydrogen and (c) carbon monoxide at different compositions from reformate gas and anode exhaust gas. The basic reactions are [16-18]:

Methanol: $2 \mathrm{CH}_{3} \mathrm{OH}+3 \mathrm{O}_{2} \rightarrow 2 \mathrm{CO}_{2}+4 \mathrm{H}_{2} \mathrm{O}$

Hydrogen: $2 \mathrm{H}_{2}+\mathrm{O}_{2} \rightarrow 2 \mathrm{H}_{2} \mathrm{O}$

Carbon monoxide: $2 \mathrm{CO}+\mathrm{O}_{2} \rightarrow 2 \mathrm{CO}_{2}$

Optimum air to fuel ratio is calculated by balancing the combustion reaction equation for the fuel. A stoichiometric mixture contains the exact amount of fuel and oxygen such that after combustion, all the fuel and oxidizer are consumed to form products. This ideal mixture approximately yields the maximum flame temperature, as all the energy released from combustion is used to heat the products [18]. The excess air stoic must be maintained across the combustor in order to avoid the temperature of the catalytic bed shooting over the required hot gas temperature of $623 \mathrm{~K}$ at outlet of combustor and to avoid catalyst deactivation. This excess air stoic is defined in equations (4) and (5) [6]:

Stoichiometric air fuel ratio:

$$
\left(\frac{\mathrm{A}}{\mathrm{F}}\right)_{\text {stoic }}=\left(\frac{\dot{\mathrm{m}}_{\text {air }}}{\dot{\mathrm{m}}_{\text {fuel }}}\right)_{\text {stoic }}
$$

And excess air stoic:

$$
\lambda=\frac{(\mathrm{A} / \mathrm{F})_{\text {real }}}{(\mathrm{A} / \mathrm{F})_{\text {stoic }}}
$$

In the design generally the approach is towards minimizing the transport limitations and maximizing the reaction rates (approaching the intrinsic reaction kinetics). The detailed numerical and empirical correlations are available from extensive experimental data for predicting the mass transfer effects and the different resistances to the reaction kinetics [9]. These effects are considered uniform across the catalyst bed for this investigation of the catalytic combustor design.

This paper reports the outcomes from design and experimental analysis of the catalytic combustor that provides heat at stable temperature to the methanol reformer. The catalytic combustor was modelled in EES and analyzed using all the three different types of fuel.

The experimental investigation was based on understanding operation and performance of the catalytic combustor, with respect to different operating fuels and their effects on the quality and quantity of heat generation for the reformer. The design was also subjected to a simulation using ANSYS DISCOVERY LIVE. It was also considered that for the lean-fuel mixture, the gaseous combustion reduction provides the rapid conversion and will not require a full simulation. Hence major side reactions can be neglected and homogeneous combustion, catalytic gas phase reactions are treated as single item for analysis [15]. The basic design includes a packed bed of combustion catalyst in $3 \mathrm{~mm}$ diameter

Published By:

Blue Eyes Intelligence Engineering \& Sciences Publication

(C) Copyriaht: All riahts reserved. 
cylindrical pellets of gamma alumina substrate coated with Platinum $\left(0.3 \% \mathrm{Pt}\right.$ on $\gamma \mathrm{Al}_{2} \mathrm{O}_{3}$ structure). The combustor generated the hot gases at temperature below $623 \mathrm{~K}$. These gases are used for supplying heat to methanol reformer and the feed vaporizer.

\section{NUMERICAL MODELLING, SIMULATION \& DESIGN}

The EES model simulation was carried out considering fuel variations as per table 1 . The same fuel configuration was used for experimental investigation.

Table-I: Fuels for experimental investigation

\begin{tabular}{|c|c|c|c|}
\hline Fuel Component & $\begin{array}{c}\text { Methanol water } \\
\text { mixture }\end{array}$ & $\begin{array}{c}\text { Reformate } \\
\text { gas }\end{array}$ & $\begin{array}{c}\text { Anode } \\
\text { exhaust gas }\end{array}$ \\
\hline $\mathrm{CH}_{3} \mathrm{OH}$ & $56.0 \%$ & - & - \\
\hline $\mathrm{H}_{2} \mathrm{O}$ & $44.0 \%$ & $13.1 \%$ & $14.0 \%$ \\
\hline $\mathrm{H}_{2}$ & - & $11.0 \%$ & $3.2 \%$ \\
\hline $\mathrm{CO}$ & - & $1.5 \%$ & $1.3 \%$ \\
\hline $\mathrm{CO}_{2}$ & - & $74.4 \%$ & $81.5 \%$ \\
\hline
\end{tabular}

This fuel mix was arrived at based on the reformate gas composition through the methanol steam reformer [3] and then the possible gas composition at the HTPEM anode exhaust. The fuel gases were simulated for experimental investigation by using premixed gas cylinders with these known compositions. The combustion catalyst considered for this investigation is commercial catalyst of $\mathrm{Pt}-\gamma \mathrm{Al}_{2} \mathrm{O}_{3}(0.3 \%$ $\mathrm{Pt}$ ) supplied by $\mathrm{M} / \mathrm{s}$. Dorf Kettle. The other catalyst properties considered for the model are as per table 2 .

Table-II: Catalyst properties

\begin{tabular}{|c|l|c|c|}
\hline Symbol & \multicolumn{1}{|c|}{ Description } & Unit & Value \\
\hline$\varepsilon$ & Catalyst bed porosity & - & 0.35 \\
\hline$\rho_{\text {bed }}$ & Bulk density of catalyst & $\mathrm{kg} \mathrm{m}^{-3}$ & 735.0 \\
\hline $\mathrm{D}_{\mathrm{p}}$ & $\begin{array}{l}\text { Catalyst particle size in packed } \\
\text { bed }\end{array}$ & $\mathrm{m}$ & $3 \times 10^{-3}$ \\
\hline $\mathrm{S}_{\mathrm{c}}$ & $\begin{array}{l}\text { Specific surface area per unit mass } \\
\text { of catalyst }\end{array}$ & $\mathrm{m}^{2} \mathrm{~kg}^{-1}$ & $210 \times 10^{3}$ \\
\hline
\end{tabular}

The generalized combustion reaction equation can be written for the fuel combustion with air consisting of $21 \% \mathrm{O}_{2}$ and $79 \% \mathrm{~N}_{2}$ [18].

$\mathrm{C}_{\alpha} \mathrm{H}_{\beta} \mathrm{O}_{\gamma}+\left(\alpha+\frac{\beta}{4}-\frac{\gamma}{2}\right)\left(\mathrm{O}_{2}+3.76 \mathrm{~N}_{2}\right) \rightarrow \alpha \mathrm{CO}_{2}+\frac{\beta}{2} \mathrm{H}_{2} \mathrm{O}+3.76\left(\alpha+\frac{\beta}{4}-\frac{\gamma}{2}\right) \mathrm{N}_{2}$

This equation (6) was solved for all the three fuels until optimal combustor outlet temperature was obtained with following assumptions and conditions [19]:

- The air fuel mix flow to the combustion catalyst bed is an axial flow.

- Heat losses from the combustor are neglected.

- Air flow coming to the combustor is at constant pressure and ambient temperature.

- Only 3 key combustion reactions are considered, and all other reactions are neglected.

- At the inlet, the flow velocity, gas composition and temperature are kept constant and considered as user input.
The findings from the EES simulation on the catalytic combustion for all the three fuels generated guidelines for the experimental investigation are as shown in table 3 .

Table-III: Fuels for experimental investigation

\begin{tabular}{|l|c|c|c|c|}
\hline \multicolumn{1}{|c|}{ Description } & UoM & $\begin{array}{c}\text { Methanol } \\
\text { water } \\
\text { mixture }\end{array}$ & $\begin{array}{c}\text { Reformate } \\
\text { gas }\end{array}$ & $\begin{array}{c}\text { Anode } \\
\text { exhaust } \\
\text { gas }\end{array}$ \\
\hline $\begin{array}{l}\text { Lower Heating } \\
\text { Value of fuel }\end{array}$ & $\mathrm{kJ} \mathrm{kg}^{-1}$ & 11824 & 13452 & 4001 \\
\hline Stoichiometric $\mathrm{O}_{2}$ & $\begin{array}{c}\mathrm{kg} \mathrm{per} \mathrm{kg} \\
\text { fuel }\end{array}$ & 0.840 & 0.889 & 0.263 \\
\hline $\begin{array}{l}\text { Possible flame } \\
\text { temperature }\end{array}$ & $\mathrm{K}$ & 1715 & 1865 & 1342 \\
\hline $\begin{array}{l}\text { Required } \\
\text { temperature }\end{array}$ & $\mathrm{K}$ & 573 & 573 & 573 \\
\hline $\begin{array}{l}\text { Excess stoic. } \\
\text { required }\end{array}$ & - & 7.40 & 8.38 & 7.08 \\
\hline $\begin{array}{l}\text { Actual air flow } \\
\text { required }\end{array}$ & $\begin{array}{c}\mathrm{kg} \mathrm{per} \mathrm{kg} \\
\text { fuel }\end{array}$ & 30.68 & 36.22 & 9.25 \\
\hline $\begin{array}{l}\text { Lower Heating } \\
\text { Value of fuel }\end{array}$ & $\mathrm{kJ} \mathrm{kg}{ }^{-1}$ & 11824 & 13452 & 4001 \\
\hline
\end{tabular}

\section{COMBUSTOR DESIGN}

Design of catalytic combustor, as shown in fig. 2, is derived from the basic numerical analysis and is finalized for experimental investigation after subjecting through a CFD analysis using ANSYS DISCOVERY LIVE. The catalytic combustor was formed out of a cylindrical packed bed design. The experimental reactor contains a $50 \mathrm{~mm}$ diameter shell having a length of $100 \mathrm{~mm}$ for the mixing chamber to ensure proper air fuel mixture. It is followed by another 100 mm length filled with 145 gm of combustion catalyst (Dorf-Kettle) pellets and an exhaust chamber to allow withdrawal of the hot gases for further analysis. The packed bed of combustion catalyst was formed out of cylindrical pellets (each of $3 \mathrm{~mm}$ in diameter and $3 \mathrm{~mm}$ in height). The combustor design incorporates the air-fuel mixing arrangement formed out of air distribution plate having 8 outlets of $10 \mathrm{~mm}$ diameter for creating swirling action of air flow and radial fuel nozzles with 6 outlets of $2 \mathrm{~mm}$ diameter. The flow paths of air and fuel being perpendicular to each other assist the proper mixing of air and fuel.

The catalyst packed bed is required to be initially heated to achieve and maintain the catalyst bed in the active temperature region ( $>373 \mathrm{~K}$ ). Then the fuel is sprayed through the fuel nozzles. The swirl cum distributor plate installed at back of fuel nozzles, helps to generate the homogeneous air fuel mixture in the mixing chamber before it reaches the catalyst surface. This arrangement of air heater, air distribution plate, mixing chamber and then the catalyst bed forms the catalytic combustor design [20].

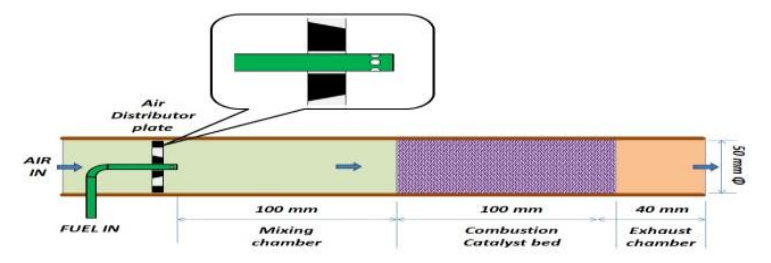

Fig. 2.Catalytic combustor design.

Published By:

Blue Eyes Intelligence Engineering \& Sciences Publication 


\section{CFD SIMULATIONS}

CFD simulations in the field of combustion are reported to be very complex. The grid generation and numerical solution to the equations can take substantial amount of time and computing power. The catalytic combustor design was also subject to a simple and quick CFD analysis using ANSYS DISCOVERY tool to derive meaningful conclusions and confirmation to validate the dimensional assumptions. By selecting the right boundary conditions, a CFD analysis became a valuable tool to model catalytic combustor configurations to get the proof on sub-models. This helped in comparing different configurations of air distributor plate, fuel nozzles and mixing chamber design. This quick analysis and ability to repeat and compare results within very short time helped in obtaining deeper understanding of the process. The CFD analysis results on finalized sub-system components of the catalytic combustor are given in fig. 3 .

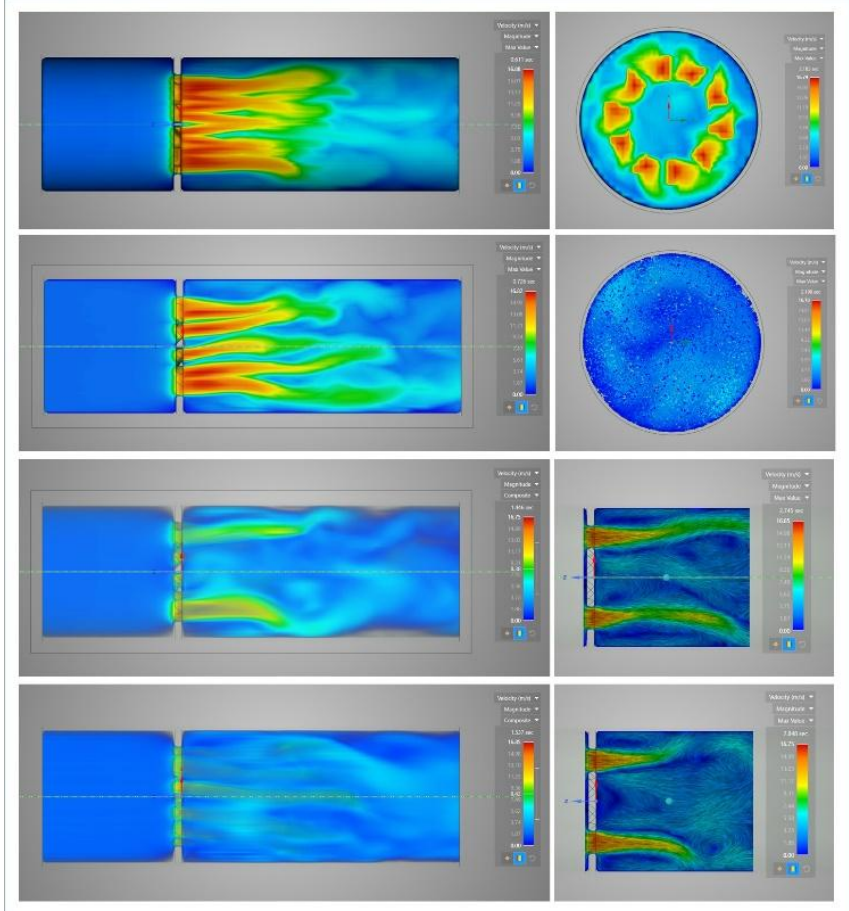

Fig. 3.Catalytic combustor - CFD analysis.

For the CFD analysis, the inlet and outlet temperature were set at $293 \mathrm{~K}$ and the outlet pressure was set to atmospheric pressure (0 bar g). The solver conditions of standard wall treatment with turbulent model of ideal compressible gas flow were used. As homogeneous mixing of air and fuel is required for effective catalytic combustion, the CFD output of velocity profiles were instrumental for deciding flow patterns and behavior post mixing chamber.

The pressure drop across the catalytic combustor sections was calculated using the formula:

$$
\begin{aligned}
& \Delta \mathrm{P}=\Delta \mathrm{P}_{1}+\Delta \mathrm{P}_{2} \\
& \Delta \mathrm{P}_{1}=\mathrm{P}_{1}-\mathrm{P}_{2} \\
& \Delta \mathrm{P}_{2}=\mathrm{P}_{2}-\mathrm{P}_{3}
\end{aligned}
$$

Where,

$\mathrm{P}_{1}=$ Pressure at inlet of air distributor plate $\left(\mathrm{mmH}_{2} \mathrm{O}\right)$

$\mathrm{P}_{2}=$ Pressure at outlet of air distributor plate $\left(\mathrm{mmH}_{2} \mathrm{O}\right)$

$\mathrm{P}_{3}=$ Pressure at outlet of catalytic combustion bed $\left(\mathrm{mmH}_{2} \mathrm{O}\right)$

The pressure drop values calculated from all three pressure values obtained from the CFD are shown in fig. 4 . These are based on assumption of the total gas flow as ambient air flow.
The pressure drop analysis enabled the design of experiment and contributed to derive the operating parameters for the experimental set-up.

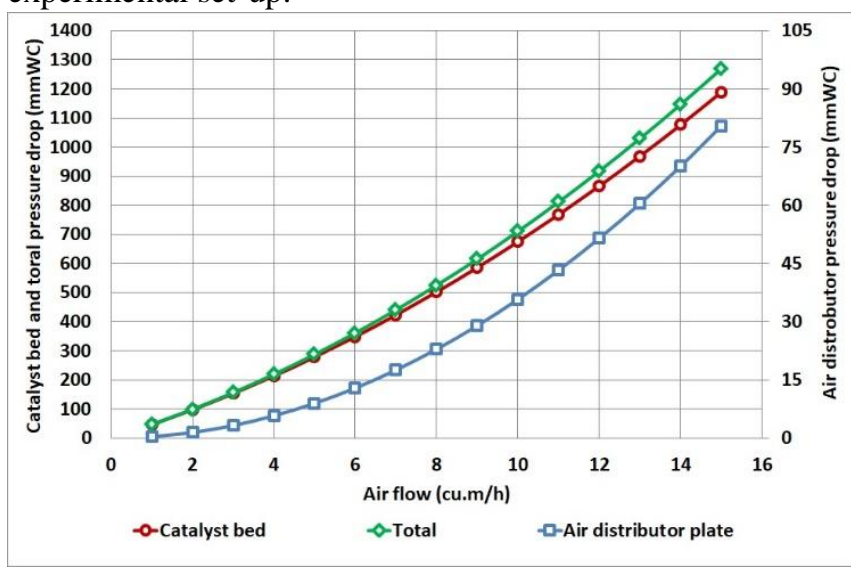

Fig. 4.Catalytic combustor - pressure drop analysis.

\section{EXPERIMENT}

The experimental set-up includes a combustion catalyst packed bed reactor, a mixing chamber, HPLC pump \& electrical vaporizer for methanol water mixture fuel, gas cylinders with premixed gas composition of reformate gas and anode exhaust gas. An air heater is provided for initial heating of air and to initialize the catalyst bed activity during start of the experiment from ambient conditions. The fuel flows are monitored and controlled through Alicat mass flow controller for gases and through HPLC pump for methanol water mix. A Honeywell MultiTrend SX paperless data recorder is used for monitoring and recording all the operating parameters.

The combustion gas temperature is measured at outlet of catalyst bed. The flow of air supplied to the catalytic combustor was modulated and controlled in such a way that the combustor outlet temperature of hot gases is maintained at temperature above $573 \mathrm{~K}$. Before start of the experiment, the catalyst bed was pre-heated to $373 \mathrm{~K}$ by controlled hot air flow, generated through electrical air heater. After achieving the temperature inside the catalyst bed, the bed was supplied with flow of all three fuels.

In the first experiment, the methanol water mixture was prepared with same steam to carbon - S/C ratio (1.4) as feed to the reformer. The methanol water mixture contained $60 \%$ methanol by volume. The fuel flow to catalytic combustor was supplied by the peristaltic HPLC pump through the electrically heated vaporizer to generate superheated vapors at temperatures above $393 \mathrm{~K}$. This air-fuel mix flow resulted in gas hourly space velocity (GHSV) across the packed bed combustor of above $20000 \mathrm{~h}^{-1}$. The fuel was sprayed into the mixing chamber using radial nozzles drilled on a fuel supply tube. The combustion reaction was carried out, which resulted in generation of hot gases. The temperature was raised from $373 \mathrm{~K}$ to $573 \mathrm{~K}$. After reaching $573 \mathrm{~K}$, the hot gas temperature was maintained by modulating the air flow at inlet of catalytic combustor with maximum flow limit of 10 $\mathrm{m}^{3} \mathrm{~h}^{-1}$. The entire stream of the hot gas mixture coming out from combustor was cooled in a water-cooled heat exchanger (cooler) to separate out

Blue Eyes Intelligence Engineering \& Sciences Publication

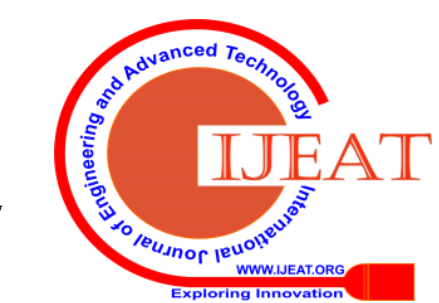


the condensable components. The non-condensable components coming out from the cooler were measured using gas flow meter. Gas samples were then collected in Tedler bags for analysis using gas chromatograph (Thermo-Scientific, TRACE 1110 with TCD and FID columns) for concentration of all the species (nitrogen, oxygen, methanol, water vapor, carbon dioxide, carbon monoxide and other pollutants such as $\mathrm{NO}_{\mathrm{X}} \& \mathrm{SO}_{\mathrm{X}}$ ). Similar experiments were carried out with reformate gas and AEG as fuel. The experimental set-up schematic is as shown in fig. 5 below.

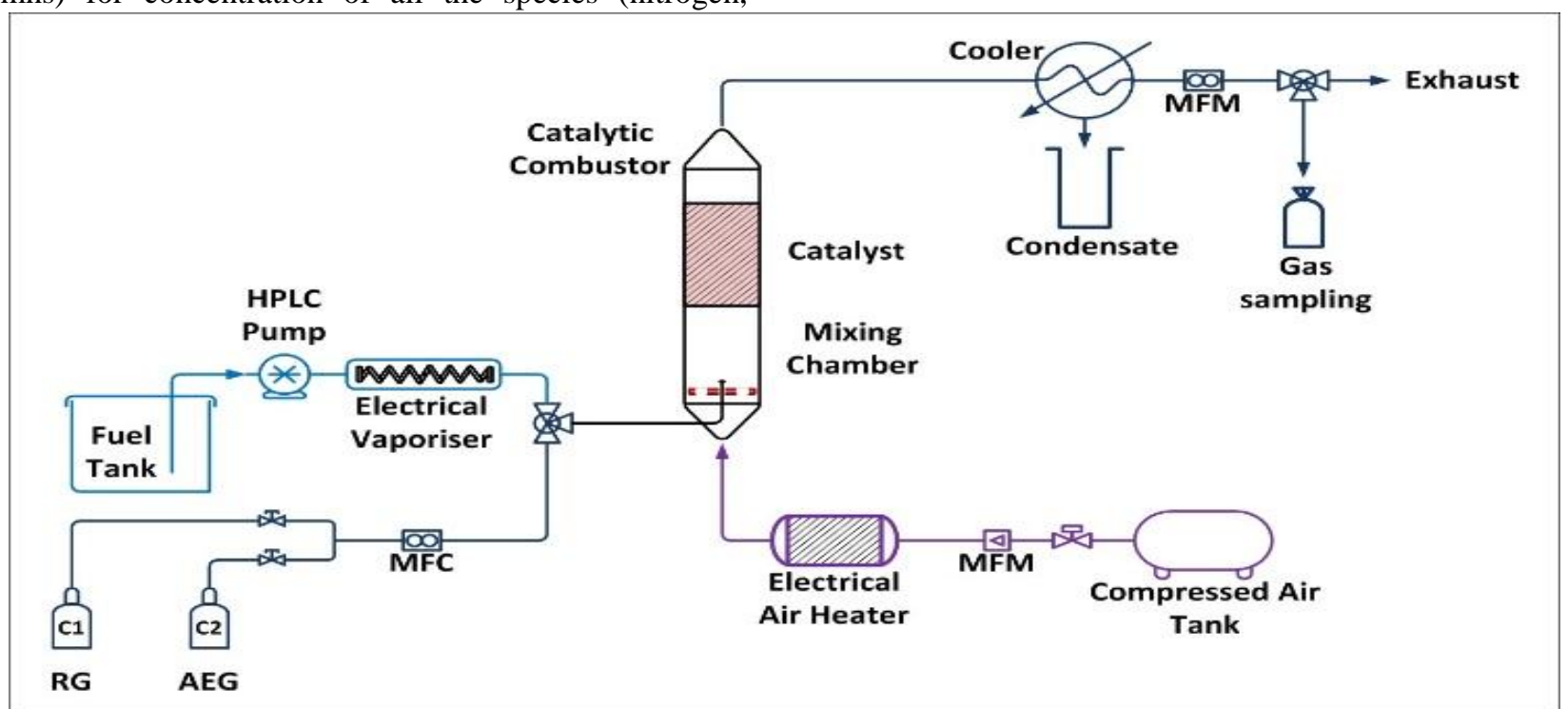

Fig. 5. Experimental assembly.

\section{PERFORMANCE}

The performance of the catalytic combustor, comprising of complete combustion of fuel and time to achieve the required hot gas temperature at outlet, was measured at various conditions. Fig. 6 shows the temperature variation of the catalytic combustor as a function of the reaction time. This plot includes the temperature variations at combustor outlet. During testing at a fuel feed rate of $3.5 \mathrm{ml} \mathrm{min}^{-1}\left(187 \mathrm{gm} \mathrm{h}^{-1}\right)$, the temperature of the catalytic combustor reached $473 \mathrm{~K}$ within 21 minutes after initiation of the combustion reaction (test 1 data in fig. 6). The fuel feed rate, air flow rate along with operating conditions were modulated to reduce the time for the start-up.

At a feed rate of $4.0 \mathrm{ml} \mathrm{min} \mathrm{m}^{-1}\left(214 \mathrm{gm} \mathrm{h}^{-1}\right)$, the combustor temperature reached $473 \mathrm{~K}$ within 15 minutes after the start of operation (test 2 data in fig. 6). It was observed that, as the fuel rate increased, the time for the start-up decreased. Similar trends were observed in test 3, 4 and 5 (shown in fig. 6). However, the combustion reaction residence time (which is inversely proportional to fuel feed rate) got reduced. Furthermore, it also increased probability of generation of hotspots in the foremost part of catalyst bed, which is expected to cause increased catalyst deterioration/ decomposition.

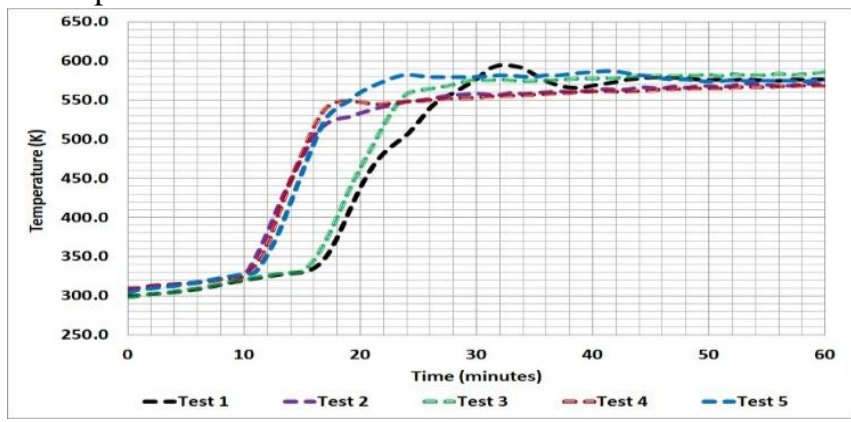

Fig. 6.Combustor tests - Temperature profiles.
To validate the design and operational performance of catalytic combustor; the EES simulation results were compared with experimental data. The experimental results are reported with respect to the complete combustion of methanol water mixture, reformate gas and AEG. The gas analysis results obtained from gas chromatography during the different experiments are shown in tables IV, V and VI along with fig. 7, 8 and 9. It was also observed that, there were no traces of unreacted fuel, $\mathrm{CO}, \mathrm{NO}_{\mathrm{X}}, \mathrm{SO}_{\mathrm{X}}$ or any particulate matter found in the combustor outlet gas.

These experiments were conducted with the guidelines derived from EES simulations. The fuel flow is arrived based on lower heating value (LHV) of fuels for to generate the necessary quantity of heat as required by the reactions of methanol reformer [3].

Table-IV: Combustor outlet gas composition for Methanol water mixture as fuel

\begin{tabular}{|c|c|c|c|c|c|}
\hline $\begin{array}{c}\text { Sample } \\
\mathbf{N o}\end{array}$ & $\begin{array}{c}\mathbf{C H}_{\mathbf{3}} \mathbf{O H} \\
\mathbf{( \% )}\end{array}$ & $\begin{array}{c}\mathbf{C O}_{2} \\
\mathbf{( \% )}\end{array}$ & $\begin{array}{c}\mathbf{O}_{2} \\
\mathbf{( \% )}\end{array}$ & $\begin{array}{c}\mathbf{N}_{2} \\
\mathbf{( \% )}\end{array}$ & $\begin{array}{c}\mathbf{C O} \\
\mathbf{( \% )}\end{array}$ \\
\hline 1 & 0.0 & 6.6 & 12.5 & 80.5 & 0.4 \\
\hline 2 & 0.0 & 6.8 & 12.4 & 80.6 & 0.2 \\
\hline 3 & 0.0 & 6.9 & 12.1 & 80.7 & 0.3 \\
\hline 4 & 0.0 & 6.5 & 12.4 & 80.9 & 0.2 \\
\hline 5 & 0.0 & 7.2 & 11.9 & 80.1 & 0.8 \\
\hline 6 & 0.0 & 6.9 & 11.8 & 81.3 & 0.1 \\
\hline 7 & 0.0 & 6.8 & 12.0 & 81.0 & 0.2 \\
\hline 8 & 0.0 & 6.9 & 11.9 & 80.8 & 0.4 \\
\hline 9 & 0.0 & 6.7 & 11.8 & 81.2 & 0.3 \\
\hline 10 & 0.0 & 6.7 & 12.5 & 80.3 & 0.5 \\
\hline
\end{tabular}


Design and Empirical Inquisition of Catalytic Combustor for Methanol Steam Reformer in HT-PEM Fuel Cell Systems

\begin{tabular}{|c|c|c|c|c|c|}
\hline $\begin{array}{c}\text { Sample } \\
\text { No. }\end{array}$ & $\begin{array}{c}\mathbf{C H}_{3} \mathbf{O H} \\
\mathbf{( \% )}\end{array}$ & $\begin{array}{c}\mathbf{C O}_{2} \\
\mathbf{( \% )}\end{array}$ & $\begin{array}{c}\mathbf{O}_{2} \\
\mathbf{( \% )}\end{array}$ & $\begin{array}{c}\mathbf{N}_{2} \\
\mathbf{( \% )}\end{array}$ & $\begin{array}{c}\mathbf{C O} \\
\mathbf{( \% )}\end{array}$ \\
\hline 11 & 0.0 & 6.9 & 11.5 & 80.7 & 0.9 \\
\hline 12 & 0.0 & 6.7 & 11.8 & 81.1 & 0.4 \\
\hline
\end{tabular}

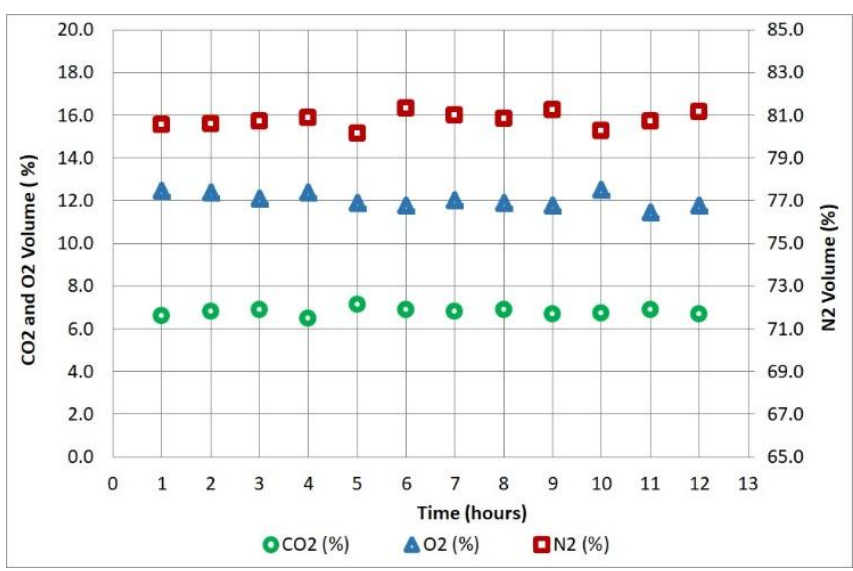

\begin{tabular}{|c|c|c|c|c|}
\hline Sample No. & $\begin{array}{c}\mathbf{H}_{2} \\
\mathbf{( \% )}\end{array}$ & $\begin{array}{c}\mathbf{C O}_{2} \\
\mathbf{( \% )}\end{array}$ & $\begin{array}{c}\mathbf{O}_{2} \\
\mathbf{( \% )}\end{array}$ & $\begin{array}{c}\mathbf{N}_{2} \\
\mathbf{( \% )}\end{array}$ \\
\hline 1 & 0.0 & 7.0 & 11.2 & 81.8 \\
\hline 2 & 0.0 & 7.3 & 11.3 & 81.4 \\
\hline 3 & 0.0 & 7.1 & 11.0 & 81.9 \\
\hline 4 & 0.0 & 6.9 & 11.4 & 81.7 \\
\hline 5 & 0.0 & 7.2 & 11.1 & 81.7 \\
\hline 6 & 0.0 & 6.9 & 11.3 & 81.8 \\
\hline 7 & 0.0 & 6.8 & 11.2 & 82.0 \\
\hline 8 & 0.0 & 7.0 & 11.0 & 82.0 \\
\hline 9 & 0.0 & 6.9 & 11.4 & 81.8 \\
\hline 10 & 0.0 & 6.9 & 11.3 & 81.8 \\
\hline 11 & 0.0 & 7.1 & 11.5 & 81.4 \\
\hline 12 & 0.0 & 6.9 & 11.2 & 81.9 \\
\hline
\end{tabular}

Fig. 7.Combustor tests - Methanol water mixture as fuel. Table-V: Combustor outlet gas composition for Reformate gas as fuel

\begin{tabular}{|c|c|c|c|c|}
\hline Sample No. & $\begin{array}{c}\mathbf{H}_{\mathbf{2}} \\
\mathbf{( \% )}\end{array}$ & $\begin{array}{c}\mathbf{C O}_{2} \\
\mathbf{( \% )}\end{array}$ & $\begin{array}{c}\mathbf{O}_{2} \\
\mathbf{( \% )}\end{array}$ & $\begin{array}{c}\mathbf{N}_{2} \\
\mathbf{( \% )}\end{array}$ \\
\hline 1 & 0.2 & 5.1 & 13.2 & 81.5 \\
\hline 2 & 0.4 & 5.4 & 13.0 & 81.1 \\
\hline 3 & 0.5 & 5.2 & 13.1 & 81.2 \\
\hline 4 & 0.6 & 5.4 & 13.3 & 80.7 \\
\hline 5 & 0.4 & 5.3 & 13.4 & 80.9 \\
\hline 6 & 0.6 & 5.4 & 13.0 & 81.0 \\
\hline 7 & 0.3 & 5.1 & 13.2 & 81.4 \\
\hline 8 & 0.5 & 5.3 & 13.3 & 80.9 \\
\hline 9 & 0.3 & 5.2 & 13.1 & 81.4 \\
\hline 10 & 0.2 & 5.4 & 13.0 & 81.4 \\
\hline 11 & 0.4 & 5.1 & 13.0 & 81.5 \\
\hline 12 & 0.6 & 5.3 & 13.3 & 80.8 \\
\hline
\end{tabular}

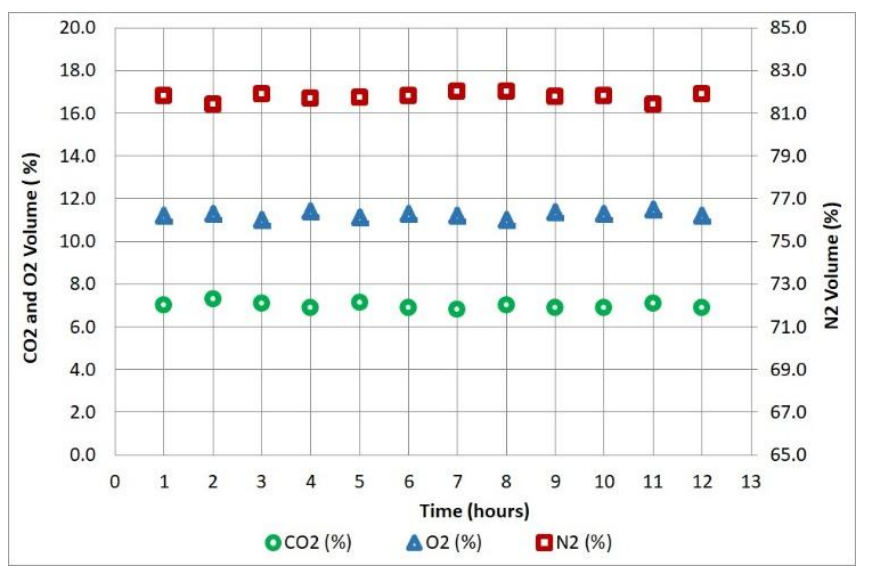

Fig. 9.Combustor tests - Anode exhaust gas as fuel.

The excess air flow was maintained across the combustor to avoid a temperature overshoot beyond $623 \mathrm{~K}$ as the temperature beyond $623 \mathrm{~K}$ would cause irreversible damage to the reforming catalyst. This resulted in air stoichiometry of 7.4 in the air-fuel mix at combustor inlet. The achieved combustor outlet gas composition was then compared with simulation results. It was found that the simulation results

and experimental investigation were in agreement for all

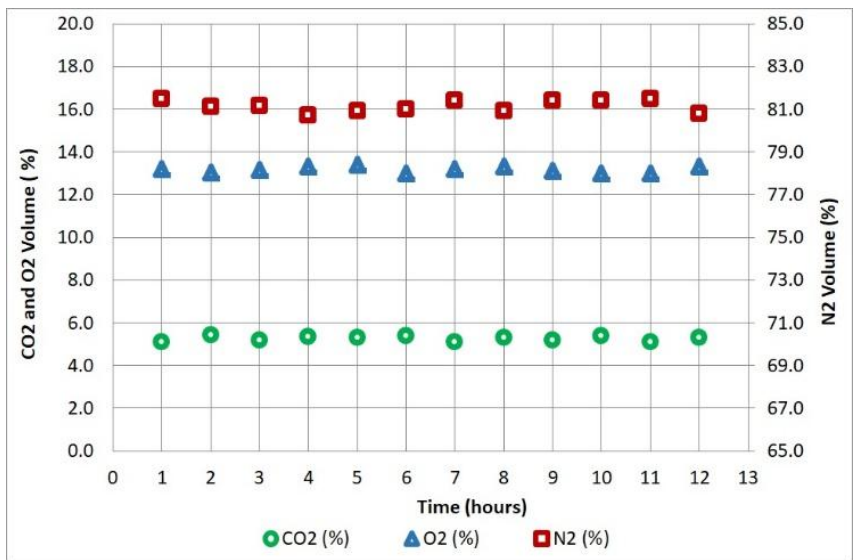

Fig. 8.Combustor tests - Reformate gas as fuel.

Table-VI: Combustor outlet gas composition for Anode exhaust gas as fuel

\begin{tabular}{|c|c|c|c|c|}
\hline Sample No. & $\begin{array}{c}\mathbf{H}_{2} \\
\mathbf{( \% )}\end{array}$ & $\begin{array}{c}\mathrm{CO}_{2} \\
\mathbf{( \% )}\end{array}$ & $\begin{array}{c}\mathbf{O}_{2} \\
\mathbf{( \% )}\end{array}$ & $\begin{array}{c}\mathbf{N}_{2} \\
\mathbf{( \% )}\end{array}$ \\
\hline
\end{tabular}
mentent on the proper air fuel mix and the operating

\section{CONCLUSION}

A new catalytic combustor concept has been developed, tested and validated for the methanol reformer. The new catalytic combustor system consists of an air distributer plate, fuel nozzles, mixing chamber and combustion chamber filled with packed bed of combustion catalyst. This catalytic combustor design was based on a steady-state analysis for combustion reaction kinetics and thermal management for providing heat for on-board methanol reformer. The design was discussed with packed bed configuration of Pt - $\gamma \mathrm{Al} 2 \mathrm{O} 3$ catalyst. The guidelines for the experiments were arrived based on the EES simulations.

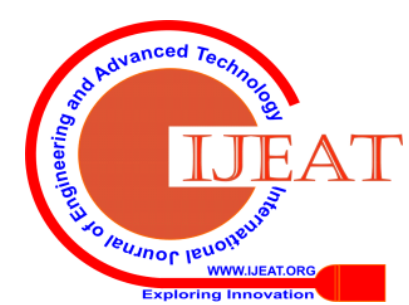


The experimental investigation was found in strong agreement the EES simulations. An analysis was done on the different fuels during normal operation of experimental methanol reformer. This investigation enabled the basic guidelines for design of catalytic combustor for on-board methanol reformer for $5 \mathrm{kWe}$ HT-PEMFC application. The final configuration of catalytic combustor will have a 105 mm diameter packed bed reactor with $225 \mathrm{~mm}$ bed length and equivalent length of mixing chamber before the catalyst bed. This has similar design configuration as that used in this experimental investigation. This guideline of combustor was estimated from minimum hydrogen flow required for the HT-PEMFC operation [3] [20].

In experimental investigation, it was observed that combustor exhaust emissions are very low (THC, CO and NOx are at nearly zero level). Thermal efficiency for hydrogen generation is higher than $80 \%$ [3]. It also achieves in a very important objective of high degree of thermal integration for efficient system operation. Recent literature also reports the sensitivity of elevated operating temperatures on reformate gas composition which will affect the fuel cell. Hence it is critical to have a controlled catalytic combustor design integrated with on-board methanol reformer for HTPEM fuel cell. This also needs further investigation towards improving the reliability of integrated methanol reformer for at least several thousand hours of operation. It should also have minimum thermal distortions during normal operation, more compactness of the system, higher efficiency and faster response.

\section{REFERENCES}

1 Atkins P, De Paula J. “Atkin's physical chemistry”. 8th ed. New York: W. H. Freeman and Company; 2006.

2 Saraswat VK, Bansal R. "India's Leapfrog to Methanol Economy". 2017.

https://www.niti.gov.in/writereaddata/files/Indias-Leapfrog-to-Metha nol-Economy.pdf

3 Chougule A, Sonde RR. "Modelling and experimental investigation of compact packed bed design of methanol steam reformer". Int J Hydrogen Energy

2019;44:29937-45 https://doi.org/10.1016/j.ijhydene.2019.09.166

4 Avgouropoulos G, Papavasiliou J, Daletou MK, Kallitsis JK, Ioannides T, Neophytides S. "Reforming methanol to electricity in a high temperature PEM fuel cell”. Applied Catalysis B: Environmental 2009;90:628-32. https://doi.org/10.1016/j.apcatb.2009.04.025

5 Andreasen S, Kær S, Sahlin S. "Control and experimental characterization of a methanol reformer for a $350 \mathrm{~W}$ high temperature polymer electrolyte membrane fuel cell system". Int J Hydrogen Energy https://doi.org/10.1016/j.ijhydene.2012.09.032

2013;38:1676-84.

6 Kim D, Jo T, Koo B, So H, Lee Y, Lee D. "Combustion characteristics of anode off-gas on the steam reforming" performance. Int J Hydrogen Energy https://doi.org/10.1016/j.ijhydene.2018.12.147 2019;44:4688-97.

7 Lee K, Yun J, Ahn K, Lee S, Kang S, Yu S. "Operational characteristics of a planar steam reformer thermally coupled with a catalytic burner". Int J Hydrogen Energy 2013;38:4767-75. https://doi.org/10.1016/j.ijhydene.2013.01.187

8 Basavaraju A, Ramesh AB, Jajcevic D, Heitmeir F. "Experimental parametric investigation of platinum catalysts using hydrogen fuel”. Int J Hydrogen Energy 2018;43:21307-21. https://doi.org/10.1016/j.ijhydene.2018.09.170

9 Sandeep KC, Mohan S, Mandal D, Mahajani S. "Determination of gas film mass transfer coefficient in a packed bed reactor for the catalytic combustion of hydrogen". Chem. Eng. Sci. 2019;202:508-18. https://doi.org/10.1016/j.ces.2019.02.042

10 Saint-Just J, Etemad S. Catalytic combustion of hydrogen for heat production. Barbir F, Basile A, Veziroğlu TN. "Compendium of Hydrogen Energy Volume 3: Hydrogen Energy Conversion”.
Woodhead Publishing Series in Energy, Oxford, 2016; 263-87. https://doi.org/10.1016/B978-1-78242-363-8.00010-4

11 Nagano S, Yamamoto S, Asano T, Ohsawa K. "Plate-type methanol steam reformer using new catalytic combustion for a fuel cell". SAE Technical Paper Series Proceedings, Soc. Automot. Eng. 2002. https://doi.org/10.4271/2002-01-0406

12 Schmidt VM, Brockerhoff P, Hohlein B, Menzer R, Stimming U. "Utilization of methanol for polymer electrolyte fuel cells in mobile systems". J of Power Sources 1994; 49:299-313. https://doi.org/10.1016/0378-7753(93)01830-B

13 R May Walter. "Reduction of thermal and prompt NOx in exhausts of natural gas fueled boilers". Copyright owned by SFA International, Inc; 2012. October 9.

14 Hayes R.E, Kolaczkowski S.T. "Introduction to catalytic combustion". Gorddon and Breach Science Publishers. ISBN: 90-5699-092-6.

15 Sui R, Liang W, Mantzaras J, Law CK. "Coupled reaction mechanism reduction for the hetero-/homogeneous combustion of syngas over platinum". Combust $\quad$ Flame 2020;214:37-46. https://doi.org/10.1016/j.combustflame.2019.12.020

16 Kim T. "Micro methanol reformer combined with a catalytic combustor for a PEM fuel cell". Int J Hydrogen Energy 2009;34:6790-98. https://doi.org/10.1016/j.ijhydene.2009.06.024

17 Chen J, Yan L, Song W, Xu D. "Catalytic Oxidation of Synthesis Gas on Platinum at Low Temperatures for Power Generation Applications”. Energies 2018; 11:1575.

18 McAllister S, Chen JY, Fernandez-Pello AC. "Thermodynamics of Combustion. In: Fundamentals of Combustion Processes”. Mechanical Engineering Series. New York. Springer; 2011.

19 Fogler HS. "Elements of chemical reaction engineering". 5th ed. Prentice Hall; 2016

20 Bell A. "Design of a Catalytic Combustor for Pure Methanol and HTPEM Fuel Cell Anode Waste Gas”. University of Toronto. 2012.

\section{AUTHORS PROFILE}

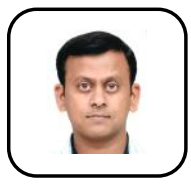

Abhijeet Chougule, received B.E. (Power Engineering) from National Power Training Institute (NPTI) Nagpur through Rashtrasant Tukadoji Maharaj Nagpur University (RTMNU) in 2007 with Gold medal. Currently he is pursuing his integrated MTech-PhD studies from the Department of Technology, Savitribai Phule Pune University, India. Since 2007, he has also been working as Scientist at Research, Technology \& Innovation Center of M/s. Thermax Ltd. Pune, India. His areas of interests are Fuel reforming, hydrogen generation and Fuel cells.

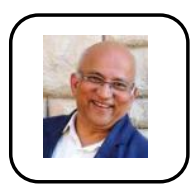

Dr. Ramakrishna R Sonde, A PhD from IIT, Mumbai, is the Executive Vice President (Research, Technology \& Innovation Center) and Member on Board of Executive Council, Thermax Ltd. Prior to Thermax Ltd. He had 23 years of working experience in Atomic Energy. He was awarded the Dr. Homi Bhabha Gold Medal by the Prime

Minister in 2006, for his outstanding contributions in the field of nuclear energy. He is a Member of the Department of Science \& Technology's Scientific Advisory committee and continues to serve as member on the IIT Senate Committee. He is a Fellow of Indian Nuclear Society and Fellow of Indian Academy of Engineering. He is currently the Chairman of the Task Force constituted by NITI Aayog on production of methanol using high ash coal. 